\title{
Impact of foreign economic sanctions on the Russian market of bonds denominated in foreign currencies
}

\author{
Alla Yakunina ${ }^{1, *}$, Yulia Semernina ${ }^{1}$, Sergey Yakunin $^{1}$ and Elena Ermakova $^{1}$ \\ ${ }^{1}$ Saratov Socio-Economic Institute of Plekhanov Russian University of Economics, Saratov, Russia
}

\begin{abstract}
The market of Russian bonds denominated in foreign currencies was considered as the primary target for the initial package of the USA and EU economic sanctions in 2014. The analyses showed that, by the end of 2017, there was a significant reduction in the number of outstanding bond issues denominated in foreign currencies and a sharp increase in the bonds nominal volume evaluated in Russian rubles. The sanctions did not lead to a significant change in the structure of the market either from the standpoint of the number of bond issues denominated in foreign currencies or in terms of their nominal value. However, the number of foreign currencies in which bond issues were denominated was reduced from 11 to 6 .
\end{abstract}

Key words: Russian bond market, bonds denominated in foreign currencies, sanctions, bond market structure

\section{Introduction}

Bonds are popular instruments in the Russian financial market [1]. The restrictive measures (economic sanctions) imposed by the USA and the EU against Russia in 2014 as a result of the Crimea crisis have had non-equal impacts on different segments of the Russian bond market.

It is worth to note that, when the first package of the restrictive measures was introduced, the market of Russian bonds denominated in foreign currencies (DFC bonds) was considered as the main "sanction goal" as it was the most closely related to foreign capital markets in terms of both the structure of its participants and its capital sources. The potential great impact of the USA and EU economic sanctions on the Russian domestic DFC bonds market was expected due to the influence of the following factors. First, the beginning of the "war of sanctions" meant an almost complete "closure" of foreign capital markets for Russian borrowers. Secondly, expecting further escalation of the "war of sanctions", foreign investors began to reduce the shares of Russian assets, including DFC bonds, in their investment portfolios. The logical outcome of the simultaneous impact of these factors was the more complicated process of attracting capital for Russian borrowers through placing the above financial instruments and the increasing competition between the latter.

\footnotetext{
* Corresponding author: alla.yackunina@yandex.ru
} 
At the same time, domestic borrowers increased their demand for financial resources, as they simultaneously faced the need to refinance existing debt denominated in foreign currencies and the need to get a kind of "replacement", albeit to a limited extent, via alternative foreign sources of financing (for example, loans from foreign banks received in foreign currency).

However, the sanctions' impact on the Russian ruble bond market is much less obvious. The main reason is the historical orientation of this market to local investors.

The main purpose of the study is to identify, substantively describe and systematize the changes that have occurred on the Russian bond market during the period of foreign economic sanctions (years of 2014-2017).

\section{Literature review}

A bond market is getting quite a lot attention in the literature. In his famous book, F. Fabozzi presented "an applied approach to understanding bond markets" [2.]. There are many interesting studies of a bond market development in different countries. P. G. Szilagyi and J. A. Batten [3; 4] investigate bond market development in Japan. I. Mathur and S. De study the dim sum bond market in Hong Kong [5]. The development of the corporate bond market in Croatia has been investigated by D. M. Sprčić and I. Wilson [6]. The paper of I. Matei is devoted to the relationship between the government bond market and real GDP growth for 16 euro zone countries [7]. Sh. Thukral, Sh. Sridhar, and M. Sh. try to understand the factors that have limited the development of Indian corporate bond markets [8]. H. Blommestein studies the impact of new regulatory factors on liquidity in government bond markets since the onset of the global financial crisis [9]. S. Babatunde and S. Perera identify and critically assess the barriers to bond financing for public-private partnership infrastructure projects in Nigeria [10].

The Russian bond market development has received attention primarily in the studies of the Russian authors. T.I. Starodubtseva and S.M. Nekrasov [11] consider certain aspects of the Russian Federation public debt management in the conditions of the geopolitical instability and foreign economic sanctions. M. V. Petrov [12] compares the attractiveness of various financing sources for corporate borrowers in the context of foreign economic sanctions, drawing attention to the attractiveness of bond financing, including DFC bonds. I.A. Alekseeva and E.V. Makarov [13] distinguish trends and evaluate the prospects for the national corporate bond market development. The authors consider foreign economic sanctions as one of the factors that provoked instability in the bond market. The mentioned above authors touch on certain aspects of the impact of the foreign economic sanctions on the domestic debt market (or its certain segments), but the authors don't get into the detailed analysis of the sanctions' impact on the Russian market of DFC bonds although it is a very important issue.

\section{Methods and Data}

We used a number of the simplest statistical methods for our analyses, among which there are methods of groupings, comparison, and dynamics analysis. In particular, the grouping method was used to make two simple groupings of bonds:

1) depending on the bonds' issuer, the following groups were indicated: government bonds, subfederal and municipal bonds, corporate bonds;

2) depending on the currency in which the bond issue is nominated, we separated bonds denominated in foreign currencies and bonds denominated in national currencies. 
Sub-federal and municipal bonds were merged into one group to comply with the rule of the absence of "empty groups" (during the entire analyzed period there were no issues of municipal bonds denominated in foreign currency on the Russian market).

On the basis of simple groupings, a two-dimensional grouping has been built, implying the allocation of six groups of bonds on the Russian bond market as a whole. The object of the research was the market for bonds denominated in foreign currency, within which the three indicated above groups of bonds were studied.

The data for the analyses was taken out of the following sources:

- data of the Internet project RusBonds managed by the information agency "Finmarket" [14];

- data reported by the analytical department of the National Association of Stock Market Participants (NAUFOR) [15];

- the Moscow Exchange data [16].

The data reported by the Finmarket's Internet project RusBonds was used to compare the structure of the Russian market of DFC bonds at the end of 2013 (before the foreign economic sanctions were imposed) and at the end of 2017 (after several years of foreign economic sanctions, which, although without regularity, were gradually tightened). The comparison of the structure of the national bond market was carried using data of the bonds nominal value, ignoring depreciation.

\section{Results and Discussion}

The Russian DFC bonds market has historically developed very disproportionately, and there were serious imbalances in the development of its separate segments yet before the introduction of foreign economic sanctions. The disproportionality of the development of the Russian DFC bonds market is obvious when one is looking at the distribution of bond issues (by their number) among individual groups, formed by type of issuers (Table 1).

Table 1. The structure of the Russian DFC bond market by the number of bond issues, as of the end of the year

\begin{tabular}{|c|c|c|c|r|}
\hline \multirow{2}{*}{$\begin{array}{c}\text { Segments of the Russian } \\
\text { DFC bonds market }\end{array}$} & \multicolumn{2}{|c|}{ Number of bond issues } & \multicolumn{2}{c|}{$\begin{array}{c}\text { The share of bond issues } \\
\text { in their total number, \% }\end{array}$} \\
\cline { 2 - 5 } & 2013 & 2017 & 2013 & 2017 \\
\hline Federal Bonds & 12 & 13 & 2.66 & 5.60 \\
\hline $\begin{array}{c}\text { Sub-federal and Municipal } \\
\text { Bonds }\end{array}$ & 1 & 0 & 0.22 & 0.00 \\
\hline Corporate Bonds & 438 & 219 & 97.12 & 94.40 \\
\hline Total & 451 & 232 & 100.00 & 100.00 \\
\hline
\end{tabular}

Source: Authors.

At the beginning of the period under consideration, the undoubtedly dominant segment (by the number of bond issues) was a segment of corporate bonds, which accounted for $97.12 \%$ of their total, while the total share of the remaining market segments was only $2.88 \%$. The introduction of the USA and EU economic sanctions impacted primarily the number of circulating bond issues, but did not lead to a radical change in its structure in the context of separate segments (Table 1).

Nevertheless, a comparison of the available data on the national DFC bonds market allows one to draw a number of meaningful conclusions: 
1) during the analyzed period, there was a sharp decrease in the total number of outstanding DFC bond issues: 232 issues by the end of 2017 as compared with 451 bond issues in 2013 (decrease by 219 issues or $48,56 \%$ );

2) the marked reduction was quite disproportional with respect to particular market segments: it affected the corporate DFC bonds segment to the greatest extent: the number of outstanding bond issues decreased by 219 issues (or $50.00 \%$ ) over the 4 years, while the sub-federal and municipal bonds segment decreased by only one bond issue (but it actually disappeared), and, at the same time, the number of outstanding federal bond issues increased by one issue (or by $8.33 \%$ );

3) during 2013-2017, there was a significant reduction in the "scale gap" between the corporate DFC bonds segment and the other segments of this market (by number of bond issues): at the beginning of this period, the corporate bonds segment was bigger than the two remaining segments by 33.7 times, while at the end of the period the corporate bonds segment still remained undoubtedly dominant but exceeded the other two segments by "only" 16.8 times.

It is also worthwhile to look at the DFC bonds market structure using face (nominal) value of bonds.

Since there were bonds denominated in different currencies at the Russian bond market in 2013, we used the Russian currency to estimate the DFC bonds market structure with respect to face value of bonds. The face value of bonds denominated in foreign currencies was recalculated using the Bank of Russia official exchange rate as of December 31, 2013 and December 31, 2017, respectively (Tables 2).

Table 2. Structure of the Russian market of bonds denominated in foreign currencies, by face value of bond issues at the end of the year

\begin{tabular}{|c|c|c|c|c|}
\hline \multirow{2}{*}{$\begin{array}{c}\text { Segments of the Russian } \\
\text { DFC bonds market }\end{array}$} & \multicolumn{2}{|c|}{$\begin{array}{c}\text { Face value of bond issues, } \\
\text { billion rubles }\end{array}$} & \multicolumn{2}{c|}{$\begin{array}{c}\text { The share of bond issues } \\
\text { in their total number, \% }\end{array}$} \\
\cline { 2 - 5 } & 2013 & 2017 & 2013 & 2017 \\
\hline Federal Bonds & 1528,947 & 3167,197 & 19,88 & 14,49 \\
\hline $\begin{array}{c}\text { Sub-federal and Municipal } \\
\text { Bonds }\end{array}$ & 18,303 & 0,00 & 0,24 & 0,00 \\
\hline Corporate Bonds & 6143,550 & 18689,472 & 79,88 & 85,51 \\
\hline Total & 7690,800 & 21856,669 & 100.00 & 100.00 \\
\hline
\end{tabular}

Source: Authors.

At the beginning of the analyzed period, the structure of the Russian DFC bond market at face value was similar (but not identical) to its structure in terms of the number of bond issues. As the most significant difference of these structures, it should be noted that the share of the federal DFC bonds segment at the face value $(19.88 \%)$ is 7.5 times its share by the number of bond issues $(2.66 \%)$, while the share of the corporate bond segment at face value, on the contrary, is lower than the share of the number of bond issues $(79.88 \%$ versus $97.12 \%)$. The discrepancy is due to the fact that the average face volume of a single bond issue in the segment of corporate DFC bonds estimated in Russian rubles (it was 14.026 billion rubles at the end of 2013) was significantly lower than the average face volume of a single bond issue in the government bond segment (127.412 billion rubles). As for the segment of sub-federal and municipal bonds, its share is $0.24 \%$ at face value and $0.22 \%$ by the number of bond issues, which are quite close.

At the same time, a number of important trends developing in this market should be highlighted:

- after the four years, there was a sharp increase in the nominal volume of the DFC bonds market estimated in Russian rubles: it amounted to 7,690.800 billion rubles at the 
end of 2013, and it was already 21,856 669 billion rubles at the end of 2017 (an increase of 14165.869 billion rubles or $184.19 \%$ );

- the sharp increase in the nominal volume of the analyzed market was caused not only by an increase in the level of activity of issuers interested in attracting bond financing in foreign currency, but also by a change in the exchange rate of the Russian ruble against foreign currencies. During this period, the Russian ruble significantly weakened against all currencies in which bonds traded on the market were nominated (for example, the US dollar against the Russian ruble rose during this period by $75.99 \%$, the Swiss franc - by $60.71 \%$, and the euro - by 53.14\%). In parallel, there was a "depletion" of the national DFC bond market in terms of the number of currencies represented on it: at the end of 2013, bonds were denominated in 11 currencies (USD, euro, Swiss franc, British pound sterling, Kazakh tenge, Norwegian krone, Singaporean dollar, Chinese yuan, Australian dollar, Turkish lira, Czech koruna) and, at the end of 2017, there were bond denominated in only 6 currencies (US dollar, euro, Swiss franc, British pound sterling, Turkish Lira, Romanian Leu) at the Russian bond market;

- while particular segments of the Russian DFC bond market were experiencing significant growth in absolute values, the change in their weights was following different directions; in particular, the share of the federal bond segment decreased by $5.39 \%$ (to $14.49 \%$ ) although its absolute volume "jumped up" by 1638.250 billion rubles (or by $107.15 \%$ ), the share of the sub-federal bond segment decreased to zero, and the corporate bond segment grew by $5.63 \%$ (to $85.51 \%$ ) while its absolute value grew by $12,545.922$ billion rubles (or 204.21\%).

\section{Conclusions and Recommendations}

To sum up we can state that the USA and EU economic sanctions against Russia had the following effects of the national DFC bond market:

1) the sanctions did not lead to a significant change in the structure of the DFC bond market either from the standpoint of the number of circulating bond issues or in terms of their nominal value (in fact, the structural hierarchy of the Russian DFC bond market segments remained unchanged: the segment of corporate liabilities retained a dominant position in absolute and relative terms, followed by a segment of federal bonds, and the last position was occupied by the segment of sub-federal and corporate bonds);

2) during the analyzed period, the structure of the national market for bonds denominated in foreign currencies was simplified, and it was because the only issue presented in the sub-federal and municipal bond segment in 2013 had been redeemed by 2017 ;

3) from 2013 to 2017, there was a significant reduction in the number of outstanding bond issues denominated in foreign currencies;

4) during the analyzed period, there was a sharp increase in the nominal volume of the DFC bond market evaluated in Russian rubles, which was due to a weakening of the national currency against foreign currencies and increasing activity of issuers in the bond market;

5) the only obvious effect of the imposed foreign economic sanctions was the "currency impoverishment" of the Russian DFC bond market, expressed in the nearly two times reduction in the number of foreign currencies in which bond issues were nominated.

Thus, the sanctions have a deterrent effect on the development of the DFC segment of the Russian bond market. At the same time, an increase in the number of foreign investors willing to buy Russian bonds would increasing the inflow of relatively cheap investment resources and, hence, would contribute to the Russian economy growth. 
In our opinion, it is possible to significantly reduce the negative impact of the sanctions through applying digital technologies for Russian bonds trading. In this regard, it is worth to follow the experience of Australia. In August 2018, the World Bank, jointly with Commonwealth Bank of Australia (CBA), the largest bank in Australia, announced the release of the world's first public blockchain bonds, called Bondi, for a total of $\$ 73$ million. According to the CBA Executive Manager James Wall, they are moving away from traditional bonds and manual labor of a registrar and a custodian to a new process that can be completely online [17].

In the post-Soviet space, there is also experience in using blockchain technologies to distribute bonds. In March 2018, the National Bank of Kazakhstan started to sell its shortterm notes within the country through a mobile application using the blockchain [18].

We believe that this experience can be used to distribute bonds issued in Russia under sanctions. In order to expand the number of potential investors, non-residents should be allowed to purchase Russian bonds. This will help attract funds from individuals and companies of other jurisdictions. To make it possible to purchase and sale bonds from any device (without brokers, dealers, commissions and taxes) it is possible to follow the experience of Kazakhstan, where investors use the Invest application, available in the Play Market and the App Store.

\section{References}

1. Y. Semernina, A. Yakunina, E. Nesterenko, S. Yakunin, E. Korobov, Evaluation of reinvestment risk for bond portfolios (in Computer Modelling in Decision Making 2017). CEUR Workshop Proceedings, (2018)

2. F. Fabozzi, Bond Markets, Analysis and Strategies. Pearson, (2013)

3. P. Szilagyi, J. Batten, Disintermediation and bond market development in Japan. International Finance Review, 4, (2003)

4. P. Szilagyi, A Perspective on Japan's Corporate Bond Market. Contemporary Studies in Economic and Financial Analysis, 86, 417-434, (2005)

5. I. Mathur, S. De, The Dim Sum Bond Market in Hong Kong. Contemporary Studies in Economic and Financial Analysis, 96, 367-388, (2014)

6. D. Sprčić, I. Wilson, The development of the corporate bond market in Croatia. EuroMed Journal of Business, 2(1), 74-86, (2007)

7. I. Matei, Euro Zone Bond Market and Economic Growth: Evidence from a Time Series Analysis. International Symposia in Economic Theory and Econometrics, 22, 39-51, (2012)

8. S. Thukral, S. Sridhar, M. Joshi, Review of factors constraining the development of Indian corporate bond markets. Qualitative Research in Financial Markets, 7(4), 429444, (2015)

9. H. Blommestein, Impact of regulatory changes on government bond market liquidity. Journal of Financial Regulation and Compliance, 25(3), 307-317, (2017)

10. S. Babatunde, S. Perera, Barriers to bond financing for public-private partnership infrastructure projects in emerging markets: A case of Nigeria. Journal of Financial Management of Property and Construction, 22(1), 2-19, (2017)

11. T. Starodubtseva, S. Nekrasova, The state and evolution of the public debt of the Russian Federation. Politics, Economics and Innovations, 7(17), (2017)

12. M. Petrov, Financing of companies in the context of economic slowdown and sanctions. Finance: Theory and Practice, 3, (2018) 
13. I. Alekseeva., E. Makarova, Russian corporate bond market: trends and development prospects. News of the Baikal State University, 3 (2017)

14. Internet project of the information agency "Finmarket" RusBonds [online]. Available at: http://www.rusbonds.ru/srch_simple.asp (2018)

15. Russian stock market: 2017. Events and Facts [online]. Available at: http://www.naufor.ru/download/pdf/factbook/ru/RFR2017.pdf (2017)

16. Annual report of PJSC "Moscow Exchange MICEX - RTS" for 2017 [online]. Available at: https://report2017.moex.com/ru (2017)

17. World Bank and CBA to issue $\$ 73$ million blockchain bonds [online]. Available at: https://forklog.com/vsemirnyj-bank-i-cba-vypustyat-blokchejn-obligatsii-na-73-mln/ (2018)

18. Central Bank of Kazakhstan launched the sale of securities on the blockchain [online]. Available at: https://bitnovosti.com/2018/03/28/tsb-kazahstana-zapustil-prodazhutsennyh-bumag-na-blokchejne/ (2018) 